Maurer School of Law: Indiana University

Digital Repository @ Maurer Law

1953

\title{
Proposed Changes in Government Contract Disputes Settlement: The Legislative Battle Over the Wunderlich Case
}

Franklin M. Schultz

Indiana University School of Law

Follow this and additional works at: https://www.repository.law.indiana.edu/facpub

Part of the Contracts Commons, and the Government Contracts Commons

\section{Recommended Citation}

Schultz, Franklin M., "Proposed Changes in Government Contract Disputes Settlement: The Legislative Battle Over the Wunderlich Case" (1953). Articles by Maurer Faculty. 2242.

https://www.repository.law.indiana.edu/facpub/2242

This Article is brought to you for free and open access by the Faculty Scholarship at Digital Repository @ Maurer Law. It has been accepted for inclusion in Articles by Maurer Faculty by an authorized administrator of Digital Repository @ Maurer Law. For more information, please contact rvaughan@indiana.edu. 


\section{PROPOSED CHANGES IN GOVERNMENT CONTRACT DISPUTES SETTLEMENT: THE LEGISLATIVE BATTLE OVER THE WUNDERLICH CASE}

Franklin M. Schultz *

$\Lambda^{\mathrm{T}}$ least since the Civil War the United States' favorite device $A$ for settling its differences with private contractors has been the so-called finality or disputes clause. This clause, now standard "boiler-plate" in practically all supply and construction procurement contracts, empowers the Government's representative, the contracting officer, to settle all disputes arising under the contract, such decision to be "final and conclusive," subject only to an administrative review. Under the "all disputes" clause the Government contracting officer decides questions of law and fact ${ }^{1}$ whereas the "fact disputes" clause leaves to his final determination only questions of fact. ${ }^{2}$ The Court of Claims had intimated in the past that the parties to the contract were not competent to decide questions of law under an "all disputes" clause, on the theory that a court could not be ousted of its jurisdiction to decide legal questions. ${ }^{3}$ Only after it was twice reversed by the Supreme Court, once per curiam, ${ }^{4}$ and once by a unanimous opinion in $195^{\circ}$ in United States v. Moorman, ${ }^{5}$ did the Court of Claims recognize the validity of an "all disputes" clause.

* Member of the Ohio Bar. A.B. Yale, I939, LL.B., I942. This article was written while the author was Associate Professor of Law, Indiana University Law School.

${ }^{1}$ See James Graham Mfg. Co. v. United States, 9I F. Supp. 7I5, 7I6 n.I (N.D. Cal. r950).

${ }^{2}$ Armed Services Procurement Regulation (hereinafter cited as ASPR) § 7-I03.I2, I CCH Gov'x ContractS REP. \ 4,06I (r947).

${ }^{3}$ See, e.g., Beuttas v. United States, 60 F. Supp. 77x (Ct. Cl. I940), rev'd on other grounds, 324 U.S. 768, 772 (I945); Braucher, Arbitration Under Government Contracts, I7 LAW \& CONTEMP. PROB. 473, 489-9I (I952).

${ }^{4}$ United States v. McShain, 308 U.S. 5I2, 520 (I939), reversing $88 \mathrm{Ct} . \mathrm{Cl} .284$ (x939).

${ }^{5} 338$ U.S. 457 . In Moorman the contractor, who had contracted to grade the site of a proposed aircraft assembly plant, disagreed with the Government as to the amount of land included under a contract which provided that both questions 
Although the contracting parties agree that the decision of the contracting officer is final subject only to administrative review, the courts have continuously made limited review available to a contractor aggrieved by such a decision. They have refused to rule that a contract providing for expert determination of disputes ousted the court's jurisdiction to decide whether the expert exercised his power of determination honestly, as contemplated by the contract. After Mr. Justice Harlan announced the opinion in Kihlberg $v$. United States ${ }^{6}$ in 1878 , the Court generally took the position that a Government officer, contractually empowered to decide disputes, occupied the position of an impartial thirdparty expert in whom both parties had placed confidence and whose considered judgment must not be supplanted by judge or jury unless it involved "fraud or such gross mistake as would necessarily imply bad faith, or failure to exercise an honest judgment ...." That the Court may have believed that this language was more than mere verbalism is seen by its disposal of a similar contract dispute between private parties. In reversing the trial judge who had instructed the jury in terms of "fraud or gross mistake," rather than "such gross mistake as necessarily implied bad faith," the Court maintained that the parties are presumed to have in mind the possibility that the arbiter might err in his determination of such matters and put their faith in his expertness. ${ }^{8}$ Nevertheless both the Supreme Court and the

of fact and contract requirements should be finally decided by the contracting officer. The contractor entered a claim for additional compensation and appealed the adverse decision of the contracting officer to the Court of Claims, which upheld the claim on the basis that the contracting officer's decision was conclusive only on questions of fact and that the dispute involved questions of law which were for the court to decide. The Supreme Court, holding that the Court of Claims should not have reconsidered the questions, recognized the right of the parties to contract for administrative determination of contract requirements, even if such determination involved questions of law.

${ }^{6} 97$ U.S. 398.

${ }^{7}$ Id. at 402 .

${ }^{8}$ Martinsburg \& P.R.R. v. March, II4 U.S. 549, 553-54 (1884). In the Martinsburg case, as in all cases down to the recent United States v. Wunderlich, 342 U.S. 98 ( 1951 ), the Supreme Court perceived (or at least, articulated) no difference between private and Government contracts, nor between an independent third-party arbiter appointed by the mutual consent of the parties and the Government's contracting officer selected by the Government and saddled with the dual responsibility of representing the Government and judging disputes to which it is a party. For a collection of the federal cases, see 94 L. Ed. 26I (I949); 96 L. Ed. II8 (I95I). See also Anderson, The Disputes Article in Government Contracts, 44 MICH. L. REv. 2 II (I945). 
Court of Claims had trouble fitting difficult cases into this formula. ${ }^{9}$ The I95I Supreme Court decision in United States $v$. Wunderlich apparently further narrowed judicial review of a contracting officer's final decision to a single ground, allegation and proof of actual fraud, that is, "conscious wrongdoing, an intention to cheat or be dishonest." 10 This new limitation on judicial review of Government contract settlement, which set off a reaction in legislative, administrative, and private circles, has led to a general re-evaluation of the disputes clause machinery. An understanding of the resulting proposals calls for a short excursion into the nature and use of the Government contract and, more particularly, the disputes clause itself.

\section{The Government's Contracting Position: Basis for the Disputes Clause}

Certainly, in an ever-growing world of specialized contracts, the Government contract stretches ordinary contract notions to the breaking point. Underlying the liberal treatment of the Government as a contracting party by the courts is the doctrine of sovereign immunity, which limits the contractor's legal remedy to such forums as the Government chooses. Before I855 Congress was the exclusive forum; the Court of Claims, and the district

${ }^{9}$ See Needles v. United States, Ior Ct. Cl. 535, 604 (r944): "the court may review an administrative decision when all the substantial evidence and relevant data known to the officer and normally considered in arriving at such a decision are against it. Under such facts the decision would be so grossly erroneous as to justify the inference of bias or bad faith." This test was first formulated by Judge Madden, concurring in Bein v. United States, Ior Ct. Cl. I44, I67 (I943). For a full analysis of the Court of Claims' verbal difficulties with the Kihlberg formula, see Braucher, supra note 3, at 494-99.

In the yo years since Kinlberg, the Supreme Court has indulged in a bit of meandering itself. See Ripley v. United States, 223 U.S. 695, 7or-02 (Igr2) ("duty that agent's judgment should be exercised, not capriciously or fraudulently, but reasonably and with due regard to the rights of both the contracting parties").

${ }^{10} 342$ U.S. 98, I00 (I95I). For proof that the Court of Claims has taken the Wunderlich fraud rule to heart, see Palace Corp. v. United States, rro F. Supp. 476, 478 (Ct. Cl. 1953): "The Supreme Court in construing the standard form of Article 15 has now limited the scope of review of decisions of heads of departments to cases in which positive fraud is alleged and proved. No fraud is alleged in this case. It would be a sheer waste of time and energies of the court and the litigants to hear evidence beyond the limits of the blueprint clearly drawn by the highest judicial authority."

A pending case in which the contractor is alleging actual fraud is A/S Jason v. United States, No. A-r 59-I33, S.D.N.Y. 
courts with limited concurrent jurisdiction, ${ }^{11}$ along with the General Accounting Office, ${ }^{12}$ are relatively recent additions. Although the Fifth Amendment precludes the Government from eliminating a private contract right, absent some paramount constitutional power, it is clear that Congress may, at will, pare down or eliminate any of these remedies. ${ }^{13}$ Perhaps because of this and because the nature of Government is not "private," the Government, as a contractor, has insisted on and received favorable treatment in its contracting capacity which it would not receive under ordinary principles of private contract law. Thus, although the United States, like General Motors or United States Steel, must operate through its agents and subagents, at the present those agents cannot bind the Government beyond their actual authority. The expansible doctrines of "apparent authority," "estoppel," and "reformation" are unavailable to the contractor who has the misfortune to deal with a mistaken or negligent agent. ${ }^{14}$ On the

11 The Act of 1855 , Io STAT. 6I2, establishing the Court of Claims to hear claims against the United States, required congressional review of the decisions, and not until a subsequent amendment in $x 863$, I2 STAT. 765 , abolishing congressional review and allowing an appeal to the Supreme Court, did the Court of Claims assume its present judicial function. For a review of its early history, see Richardson, Historx, Jurtsdictron, and Practice of the Court of Clatms of tHe UnIted States (2d ed. I885).

These early statutes were superseded in 1887 by the Tucker Act, permitting the United States to be sued in the Court of Claims in any amount and in the United States district courts in an amount not in excess of $\$ 10,000$ in actions based "upon any contract, expressed or implied, with the Government of the United States, or for damages, liquidated or unliquidated, in cases not sounding in tort." 24 STAx. 505 (1887). The statute has since been incorporated in 28 U.S.C. \& I 49 I (Court of Claims), § 1346 (district courts) (Supp. I952).

12 The Comptroller General bases his power to determine the Government's contract liability on $\S 305$ of the Budget and Accounting Act, 42 STAT. 23 (I92I), 3I U.S.C. § 7I (I946), which provides that "all claims" against the Government "shall be settled and adjusted in the General Accounting Office." The I92I act abolished the office of Comptroller of the Treasury, an official who, since I868, had been empowered to determine conclusively what balances remained in the Treasury for use by each of the executive departments. For a general treatment of the position of the Comptroller General, see MANsfiedd, THE Cosmtrolier GeNeraI (I939).

${ }^{13}$ Lynch v. United States, 292 U.S. 57 I (I934).

${ }^{14}$ See Kesster and Sharp, Contracts, Cases and Materiats 780,788 and passim (I953). For comment on the proposed "Good Faith Reliance Act" see Newman, Should Official Advice Be Reliable? - Proposals as to Estoppel and Related Doctrines in Administrative Law, 53 CoL. L. REv. 374 (I953). Perhaps the harshest recent example of the Supreme Court's adherence to Holmes' "square corners" approach was Federal Crop Ins. Corp. v. Merrill, 332 U.S. 380 (1947) (5-4 decision). 
other hand the courts freely allow the Government the privilege of insisting on firm offers without consideration, ${ }^{15}$ the power to insist on requirements as to writing covering more contracts than the Statute of Frauds, ${ }^{16}$ the right to make agreements exempt from the statute of limitations, ${ }^{17}$ and the unlimited option to terminate contracts for the convenience of the Government. ${ }^{18}$

Another peculiarity is that the Government in some of its operations unavoidably assumes the role of the monopolist with power for both legal and economic coercion. To cite one recent legal example, the Selective Service Act of 1948 permits seizure of the facilities of a manufacturer who refuses or fails to comply with a mandatory order placed for the delivery of goods for the armed services. ${ }^{19}$ The possibility of economic coercion arises during full-scale mobilization when the Government, through a system of priorities, becomes the sole buyer of a particular commodity. Similarly, in negotiating its contracts, the Government, as draftsman, uses standard forms which dictate the general conditions of performance, including the disputes clause. A bidder

${ }^{15}$ A recent example is Refining Associates, Inc. v. United States, Iog F. Supp. 259 (Ct. Cl. 1953), holding that a bidder could not withdraw its bid after the opening but before the award where the bidder had agreed to keep the bid open for I $_{5}$ days after the opening. Interestingly enough, the Court of Claims accepted the incorporation of a provision prohibiting withdrawal without questioning the absence of consideration.

${ }^{10}$ The statutory signed writing requirement was eliminated by 65 STAT. 70r (I95I), but Army regulations continue to require writings. See, e.g., ASPR § I-20r.6, I CCH Gov'T Contracts REP. If I9,IO2 (I953): "All purchase transactions made by a Contracting Officer will be evidenced by written contracts . . . on approved contract forms ...." See Note, 27 IND. I.J. 279 (I952).

${ }^{17}$ United States v. Nashville, C. \& St. L. Ry., II8 U.S. I20 (I885).

${ }^{18}$ See ASPR \$\$ 8-700 et seq., 2 CCH Gov'T CoNTraCTs RER. II 4I, 860 (I953). This right to terminate was first recognized in United States v. Corliss SteamEngine Co., 9 I U.S. 321 (1875).

${ }^{10} 62$ StaT. 625 (I948), 50 U.S.C. App. $\$ 468$ (Supp. I952). This may be invoked "whenever the President after consultation with and receiving advice from the National Security Resources Board determines that it is in the interest of the national security for the Government to obtain prompt delivery of any articles or materials the procurement of which has been authorized by the Congress exclusively for the use of the armed forces of the United States, or for use of the Atomic Energy Commission ...." For the Government's power to conscript industry during World War II, see War Labor Disputes Act, 57 Star. I63 (I943), the constitutionality of which was supported in the Montgomery Ward litigation. United States v. Montgomery Ward \& Co., 58 F. Supp. 408 (N.D. Ill.), cert. denied, 324 U.S. 858, rev'd, I50 F.2d 369 (7th Cir.), vacated, 326 U.S. 690 (I945). The Defense Production Act of 1950 , 64 STAT. 799, as amended, 50 U.S.C. APP. \$ $208 \mathrm{I}$ (Supp. I952), also gives the President broad powers to requisition equipment and supplies for the national defense upon payment of just compensation. 
who sought to eliminate the disputes clause would no doubt be disqualified; a procurement officer who eliminated it would not bind his department. ${ }^{20}$

Perhaps Mr. Justice Douglas had this unbalanced picture in mind when he dissented in Wunderlich. He speaks of the contracting officer as a potential tyrant with "the power of life and death over a private business even though his decision is grossly erroneous. Power granted is seldom neglected . . . . The rule we announce makes Government oppressive." 21 Presumably Mr. Justice Douglas envisioned the case of the small, helpless, dependent businessman whose very livelihood is subject to the whims of some capricious Government "bureaucrat" - a case of David against Goliath.

This is one side of the coin. The picture on the other side is sketched by Mr. Justice Minton for the majority in Wunderlich:

Respondents [the dam contractors] were not compelled or coerced into making the contract. It was a voluntary undertaking on their part.

${ }^{20}$ For a contrary view on the dominant role of the Government as contractor, see Mr. Justice Frankfurter, dissenting in United States v. Bethlehem Steel Corp., $3 \times 5$ U.S. 289, 336 ( 9 $_{942}$ ): "During wartime the bargaining position of Government contracting officers is inherently weak, no matter how conscientious they may be .... It is not difficult in these days to appreciate the position of negotiators for the Government in time of war and to realize how much the pressures of war deprive them of equality of bargaining power in situations where bargaining with private contractors is the only practicable means of securing war supplies . . . " It has also been argued that, while standardized, the Government contract is by no means one-sided, because so much of the normal financial risk has been taken out of it. Escalator and price redetermination clauses present one facet of this point of view; the Contract Settlement and War Hardship Acts represent another. For an instructive analysis of World War II procurement in these terms, see Fain and Watt, War Procurement-A New Pattern in Contracts, 44 Cor. L. REv. 127 (I944). Financial underwriting of both large and small contractors, even to the point of bailing them out of impending bankruptcy, is still another index of the reduced risk in contracting with the Government. For a Korean War case study, see Cary, Government Financing of Essential Contractors: The Reorganization of the Glenn L. Martin Co., 66 HARv. L. REv. 834 (I953).

${ }^{21} 342$ U.S. 98 , IOI 02 (I95I). Mr. Justice Reed joined in this dissent. Mr. Justice Douglas' views were foreshadowed by his dissent in United States v. Holpuch Co., 328 U.S. 234, 243 ( 1946 ), pointing out the unfairness in holding a contractor to a literal reading of the contract. See also his opinion for the Court in Priebe \& Sons v. United States, 332 U.S. 407 (I947), refusing to permit the Government to use a liquidated damage clause as an in terrorem remedy to expedite the lend-lease program. He also joined in Mr. Justice Jackson's pungent dissent in Federal Crop Ins. Corp. v. Merrill, 332 U.S. 380, 386 (I947). Mr. Justice Jackson dissented from the Wunderlich opinion on the ground that it narrowed the Court's traditional test by eliminating the alternative of "such gross mistake as necessarily implied bad faith." 342 U.S. at IO2 (I95I). 
As competent parties they have contracted for the settlement of disputes in an arbitral manner .... The limitation upon this arbitral process is fraud, placed there by this Court. If the standard of fraud that we adhere to is too limited that is a matter for Congress. ${ }^{22}$

Apparently, Mr. Justice Minton had the notion that the contracts involved were made as a result of arm's length bargaining. To extrapolate somewhat freely, his mental image is of a contractor operating vis-à-vis the Government in a balanced market, one who can take the Government's business or leave it alone. It is of a contractor well-advised by competent counsel concerning the bite of the finality clause who should, perhaps, be expected to include in his bid the appropriate cost of potential arbitrary and capricious conduct on the part of the contracting officer. ${ }^{23}$ In fact, in the Wunderlich case the Government argued that "in an effort to avoid expensive and time-consuming litigation of technical factual disputes, the Government bargains and pays for inclusion of Article I5 in its standard construction contract." 24 No one, of course, has made a field study to determine whether the contractor translates the potential arbitrariness of the contracting officer into a cost item in the various types of cost and lump-sum contracts utilized in the Government's mammoth procurement program. Nor has anyone explored the related question of the relative bargaining power of the "average" prime contractors vis$\grave{a}$-vis the Government.

While a unique form of economic power as employed by the Government, the disputes clause is actually a development from similar settlement provisions in private contracts. The Standard Form of Arbitration Procedure of the American Institute of Architects calls for submission of disputes to one or three arbitrators

${ }^{22} 342$ U.S. 98 , I00 (I95I).

${ }^{23} \mathrm{It}$ is perhaps reminiscent of Wells Bros. Co. v. United States, 254 U.S. 83, 87 (I920): "Men who take million dollar contracts for Government buildings are neither unsophisticated nor careless. Inexperience and inattention are more likely to be found in other parties to such contracts than the contractors, and the presumption is obvious and strong that the men signing such a contract as we have here protected themselves against such delays as are complained of by the higher price exacted for the work."

${ }^{24}$ Government's Petition for Certiorari, p. I4; see also Brief for the United States, p. I5: "Like every other provision of a Government contract, it is an element which doubtless affects the contract price. If the provision be deemed advantageous to the Government, the advantage has been bought and paid for and is entitled to as much effect as other agreements to arbitrate differences . . . ." 
appointed by the parties. ${ }^{25}$ While a decision after a hearing is final, this procedure differs from the Government disputes mechanism in that the arbitrator with the decisive voice is not in the pay of one of the parties.

Perhaps more closely analogous to the Government disputes clause are those private contracts which make the supervising expert the sole arbiter rather than provide for full-fledged arbitration of the AIA variety. Despite the fact that the expert is one who has supervised the performance out of which the dispute arises and is in the pay of the owner, Corbin concludes that the decision of the hired expert is given as great weight in the courts as the award of a disinterested arbitration panel. ${ }^{26}$ But there is one vital difference in the case of a Government contract which the courts fail to recognize: while the architect or engineer who judges a dispute between his client, the owner, and the contractor acts in a professional, quasi-judicial capacity, the non-licensed contracting officer is not subject to professional standards or discipline when he decides disputes between his principal, the Government, and the contractor. ${ }^{27}$

\section{Administrative Review}

\section{A. Function of the $A S B C A$}

Recently, the Government has answered this implied charge of unfairness by pointing to the contractual departmental review provided by its boards of contract appeals as surrogates for independent third-party judgment. In most contracting agencies review by the department head has, since World War II, been formalized by delegation to a "duly authorized representative," namely, a board of contract appeals, which provides the aggrieved

${ }^{25}$ Art. 39, The General Conditions of the Contract for the Construction of Buildings, AMERTCAN Institute of ARCHITECTs, HandBoOK OF ARCHTECTURAL PrACTICE I69-7I (6th ed. I95I) (AIA Doc. No. 305).

${ }^{26} 3$ CoRbin, ConTracts $\$ 652$ (I95I).

27 The contracting officer is a ubiquitous character. He may be a Reserve or Regular Army officer, or a civilian governmental employee. His background may be engineering, business, or nothing even slightly related to the contract in question. One contracting officer has described his job as a combination of "accountantauditor-engineer-business man." In the Air Force there are currently three types of contracting officers: Procurement (negotiates the contract), Termination (handles "termination for the convenience of the Government"), and Administrative (serves on the job). The Administrative Contracting Officer is the one currently under discussion. 
contractor, in the language of the broader disputes clause, the "opportunity to be heard and offer evidence in support of its appeal." ${ }^{28}$ At present, the armed services, the Corps of Engineers, the General Services Administration, the Atomic Energy Commission, and the Commodity Credit Corporation operate such boards, while the Departments of Interior and Commerce, which also carry on large procurement programs, do not. ${ }^{29}$ The oldest of these boards, the Defense Department's Armed Services Board of Contract Appeals (ASBCA), provides a de novo review of the contracting officer's decision. The officer's "findings of fact are not evidence in refutation of sworn testimony"; ${ }^{30}$ "they are more like pleadings ...." 31

The ASBCA, which is composed of fifteen members appointed by the department secretaries, is divided into three panels: the Army Contract Appeals Panel with nine members (further divided into three divisions), the Navy Contract Appeals Panel with three members, and the Air Force Contract Appeals Panel with three members. Each member is an experienced lawyer; none has served in a defense agency in any procurement capacity. Each appeal is heard by one member of the appropriate panel or division. The contractor may appear in person or be represented by counsel. The actual hearing has recently been described by a Board member in these terms:

The parties may offer at the hearing such evidence or arguments as they deem appropriate subject, however, to the exercise of reasonable discretion by the presiding member in supervising the extent and manner of presentation. Evidence other than that ordinarily admissible under the

${ }^{28}$ For the Defense Department's present disputes clause, see note $6_{3}$ infra.

${ }^{29}$ For descriptions of the various boards' operations and rules of procedure, annotated, see I CCH Gov'r Contracts REP. I Io,72I (I95I) (ASBCA); I id. II I0,75I (I95I) (General Services Administration Board of Review); I id. II ro,76r (I95I) (Atomic Energy Commission Advisory Board of Contract Appeals); I id. I I0,77I (I95I) (Contracts Disputes Board for Commodity Credit Corporation); 2 id. II 24,804 (I95I) (Corps of Engineers Claims and Appeals Board, from which appeal lies to the ASBCA on all military contracts).

${ }^{30}$ Kirk, BCA No. I, I Contract Cas., Fed. I68 (I943), cited in AUstin, Digest of Decisions of the ArMy BoARD of Contract AppeaIs, I942-50 206 (I95I).

${ }^{31}$ Settergren, BCA Nos. $\mp 64,218$, I Contract Cas., Fed. 87 (I943), Austnd, op. cit. supra note 30 , at 206. Compare I CCH Gov'T ConTraCts REP. II Io,76I, § 3.22 (I95I): "Scope of the Proceedings. At a hearing the Board shall receive evidence and arguments presented by or on behalf of the parties. The appeal will be considered de novo and independent findings of fact will be made, although the findings of fact of the contracting officer may be adopted by the Board in whole or in part." 
generally accepted rules of evidence may be received in evidence at the discretion of the presiding member. The degree of formality of the hearing depends upon the circumstances of the particular appeal .... On a few occasions contractors have been more interested in getting something off their chests, as they put it, than in the final results of their appeals. The presiding member, sensing such a situation, is generally liberal in his rulings. On the other hand, if the issues are important or the parties are represented by counsel, the hearing will be very much like a court trial without a jury..$^{32}$

The testimony and argument are recorded verbatim and the parties have the right to file briefs. The presiding member drafts a decision which is submitted to the other members of his panel for approval. When a majority of the panel approves, the decision becomes the decision of the panel and Board, provided that all three panel chairmen agree that a review by the full Board is not required. If a majority of the panel members cannot agree, or if one or more panel chairmen do not waive review by the full Board, the decision is then made by a majority of the members of the full Board. Either party may move for a reconsideration. The decisions are made in writing, and are available for public inspection at the office of the Board in the Pentagon, but are not officially published. Several unofficial digests are available. ${ }^{33}$

The use of the administrative review varies with the type of clause involved. Where the "all disputes" clause is inserted in the contract, the contractor must first exhaust his administrative remedies before bringing a court action. In case of the more widely used "fact disputes" clause the contractor must also take his administrative appeal on fact questions but is free to seek damages immediately on issues of law in the General Accounting Office, the Court of Claims, or a district court, in so far as the latter has concurrent jurisdiction. Yet, because of the elusive distinction between fact and law which the cases reflect, it is wise for a contractor to take his administrative appeal lest he be thrown out of

${ }^{32}$ Cuneo, Armed Services Board of Contract Appeals: Tyrant or Impartial Tribunal?, 39 A.B.A.J. 373, 435 (I953). Information about the operation of the ASBCA was obtained from Mr. Cuneo's article and a personal interview with him in Washington in August I953. Mr. Cuneo has been a member of the .4SBCA and its predecessors since I946. See also Austin, President of ASBCA, testifying, Hearings before Subcommittee of the Senate Committee on the Judiciary on S. 2487, 82d Cong., 2d Sess. 93-95 (I952).

${ }^{33}$ Cuneo, supra note 32 . 
court for having failed to exhaust his administrative remedy on what turns out to be an issue of fact. $^{34}$

The Defense Department quickly recognized that the ASBCA could not consider questions of fact under a fact disputes clause without dealing with questions of law. Consequently, the ASBCA charter empowers the Board, in its discretion, to "hear, consider, and decide all questions of law necessary for the complete adjudication of the issue." ${ }^{35}$ However, reversal of the contracting officer's decisions on a question of law in such a case is not binding on the GAO or the Court of Claims. ${ }^{36}$

It is doubtful whether an ASBCA proceeding approximates the formality of an agency hearing subject to full Administrative Procedure Act requirements. A Board member does not have all the hearing powers called for by Section 7 of the APA. For example, while he may cause depositions to be taken, he is without authority to subpoena a witness. ${ }^{37}$ The APA evidence requirements are not met; nor do the parties have a reasonable opportunity to submit proposed findings and conclusions or exceptions to decisions or recommended decisions. ${ }^{38}$ In recognition of this disparity between informal board procedures and APA minimum requirements, several boards have explicitly disclaimed the applicability of the APA to their proceedings. ${ }^{39}$

${ }^{34}$ See United States v. Blair, 32I U.S. 730, 734 (I944); Kennedy, The Conclusiveness of Administrative Findings in Disputes Arising under Government Contracts, 4 BAYLOR L. REV. I60, I66 (I952).

${ }^{35} 32$ CODE FED. REGS. following § 4I3.008 (I95I). It continues: "Unless the contract provides otherwise, when in the consideration of an appeal it appears that a claim for unliquidated damages is involved therein, the Board shall, insofar as the evidence permits, make findings of fact with respect to such claims without expressing an opinion on the questions of liability." For a full discussion of the ASBCA's authority and jurisdiction, see Etheridge, Appeals from Administrative Decisions in Government Contract Disputes, $3 \mathrm{I}$ TEXAS L. REv. $55^{2}$ (I953). Questions of rescission or reformation of a contract, quantum meruit and quasicontract are all outside the Board's jurisdiction. Id. at 557 .

${ }^{36}$ Bell Aircraft Corp. v. United States, roo F. Supp. 66 1 , 696-99 (Ct. Cl. r95I), aff'd by an equally divided Court, 344 U.S. 860 (I952), where the Court of Claims discussed the Board's treatment of questions of law under a fact disputes clause but gave it no weight and decided the case the other way.

${ }^{37}$ See Smith, The War Department Board of Contract Appeals, 5 FED. B.J. 74,

79 (r943).

${ }^{38}$ See 60 STAT. 24I, 242, 5 U.S.C. \$§ I006-07 (I946).

${ }^{39}$ See I CCH Gov'T Contracts REP. I Io,77I, § 400.I (f) (I95I), which provides that "The provisions of the Administrative Procedure Act . . . are not applicable to proceedings before the Board [the Contracts Disputes Board of the Commodity Credit Corporation] except those requirements [of Section 3 on public information]. ... The Board does not issue opinions." See Clifton, BCA 
It is equally clear that the ASBCA proceedings fall far short of a court trial, as afforded, for instance, by the Court of Claims under its new rules. ${ }^{40}$ The Court of Claims' commissioner system provides the full panoply of pleading, proof, and argument provided in a federal district court; in contrast, the ASBCA stresses informal adjudication. Unlike judges, the Board members are not appointed by the President with the consent of the Senate nor granted security of tenure.

What of the analogy to a submission to arbitration? Again, as in the case of the contracting officer, the basic difference is that the contractor has no voice in the appointment of the Board, which is the "secretary's duly authorized representative." The Defense Department's fact disputes clause provides in the disjunctive for a decision by "the Secretary or his duly authorized representative for hearing of such appeal." It has been contended by individual board members that the Board is independent of the Defense Secretary's control, and that no decision is ever subject to review at Department head level:

The Secretaries of the Army, Navy and Air Force do not interfere with the preparation of decisions. The Board at no time communicates with the Secretaries or their staffs as to how an appeal should be decided. The Board is above and apart from the procuring activities. In the performance of their duties the Board members never see a contracting officer except when one testifies at a hearing. ${ }^{41}$

Be that as it may, no contractor is likely to have the confidence in a Board member that he would have in an arbitrator he had a

No. I20I, Austin, op. cit. supra note 30 , at 5, where the ASBCA held that the APA was not applicable as to the time for taking an appeal. Compare I CCH Gov' CoNTRACTS Rep. If ro,76I, \& 3.23 (I95I): "Conduct of hearings. - The hearings before the [AEC] Board will be informal, with no fixed form of procedure, and the manner in which facts are found and conclusions reached shall be a matter for the discretion of the Board . . . ." It should also be noted that the Administrative Procedure Act, 60 Srar. 237 (I946), as amended, 5 U.S.C. § I00I(a) (I952), specifically excludes functions conferred by the Contract Settlement Act of r944, parts of which are subject to ASBCA jurisdiction under its charter. See Cuneo, supra note 32 , at 376 .

${ }^{40}$ Rules of the United States Court of Claims (revised Oct. I5, I953). See Smith, supra note 37 , at 82 : "The Board is not a judicial body, but an administrative one. Though there is a degree of formality in the proceedings before the Board, they are really informal as compared to court procedure, and strict rules of evidence are not usually observed."

${ }^{41}$ Cuneo, supra note 32 , at 436 . 
hand in selecting, particularly where the member is on the payroll of the service against which he is prosecuting his claim. Appointment by the Secretary of Defense rather than the secretary of the particular service would make for greater independence and confidence. ${ }^{42}$

So much for the merits of the review provided the aggrieved contractor by the administrative boards of contract appeal. It should be noted that some department heads may provide only for an administrative appeal to the Secretary, himself, as was the case in Wunderlich. ${ }^{43}$

In considering the finality of an architect's, engineer's, or supervising expert's decision under a private contract disputes clause, Corbin notes that the decision is equally conclusive against the expert's own employer. ${ }^{44}$ This point was clearly made in Kihlberg as to finality against the Government, ${ }^{45}$ and has been followed, without deviation, by the Supreme Court as well as the Court of Claims. Despite the fact that recent forms of the disputes clause provide for an appeal by the contractor and thus a second de novo administrative determination by the department head or his representative board, the Government has never been permitted to reopen the contracting officer's unfavorable decision on a collateral matter at this level. ${ }^{46}$ As the Justice Department's representative pointed out in the hearing on the McCarran Bill (S. 24), the disputes clause is a one-way street, with administra-

${ }^{42}$ See letter from O. P. Easterwood, Jr., Hearings, supra note 32, at I20.

${ }^{43}$ See Gaskins testifying in Hearings, supra note 32, at 35:

I would like to make one further statement with respect to Mr. Phillips' testimony. He told of the very thorough quasi-judicial review which is afforded by the Armed Services Board of Contract Appeals.

Well, it so happens that the War Department is responsible for letting only a portion of the contracts in which the United States is interested, and a very material part of all of the contracts are let by the Bureau of Reclamation, having to do with many of the big dams out West, the power projects, and things of that character.

Now that, of course, is under the Department of Interior. And the Department of Interior has no formalized procedure for the hearing of appeals from decisions of the contracting officer.

You may write a letter to the Department of the Interior, and they will consider the appeal on the basis of your letter. If you want to talk to them personally, they will assign a lawyer in the Solicitor's Office to listen to what you have to say. But the various steps described by $\mathrm{Mr}$. Phillips do not exist as regards many of the departments which are now engaged in letting Government contracts.

A similar procedure is apparently followed by the Department of Commerce.

${ }_{44} 3$ CORBIN, CONTRACTS $\$ 652$ (I95I).

${ }^{45}$ Kihlberg v. United States, 97 U.S. 398, 402 (1878).

${ }^{46}$ See Bell Aircraft Corp. v. United States, roo F. Supp. 66I, 69I (Ct. Cl. I95I), aff'd by an equally divided Court, 344 U.S. 860 (I952). 
tive appeal from the contracting officer's decision open to the contractors, but not the Government.

So that if 20 disputes involving questions of fact arise and are decided by the contracting officer during performance of a contract and the contractor seems unduly advantaged by the decision of two such disputes, but the Government appears to have been favored in the decision of two others, only the latter two rulings will be appealed and if found to be erroneous, will be corrected. ${ }^{47}$

Thus taken in conjunction with the present finality of the contracting officer's decision vis-à-vis the Government, the department's administrative review may be as favorable to the contractor as comparable administrative and judicial reviews in, for instance, tax disputes, where the Government's power to withdraw concessions made to the taxpayer by any lower echelon administrative officer is reserved. ${ }^{48}$

\section{B. The Place of the General Accounting Office}

By Section 305 of the Budget and Accounting Act of I92 I, Congress provided that claims by and against the United States shall be settled and adjusted in the General Accounting Office. ${ }^{49}$ The GAO, while not a party to the contract, may enter the picture whenever vouchers are presented to it by an administrative agency for "direct settlement" with a contractor, or whenever a disbursing officer or head of an administrative agency requests an advance decision. The GAO also enters the picture when a contractor makes a claim against the United States where payment has been denied. It can deny payment or demand payment back; if the latter is refused, it can collect directly from any other governmental funds that may be due a contractor, and failing that method, it may request that the Attorney General sue on behalf

47 Testimony of Phillips, Hearings, supra note 32 , at 16 .

48 Any concession made by an administrative officer of the Internal Revenue Service may be withdrawn at any stage of the administrative proceeding (but note the emerging policy to make such administrative concessions more conclusive, Int. Rev. Mimeo. No. 298, Oct. 9, I953, 4 P-H I953 FEd. TAx Serv. I 76,703). In fact, even after issue is joined in a Tax Court proceeding to review a deficiency formally asserted by the Commissioner, the Commissioner retains the power until the date of hearing or rehearing in the court to claim any additional deficiency. INT. REv. CODE $\$ 272(e)$. Actually there is no formal administrative mechanism barring a Government tax claim open under the statute of limitations except a closing agreement signed by the Secretary of the Treasury, the Under-Secretary, or an Assistant Secretary. INT. REv. Cone § 3760 .

${ }^{49}$ See note i2 supra. 
of the United States in the appropriate court. ${ }^{50}$ It can also pay claims denied by the contracting agency, and a contractor dissatisfied with a decision of a contracting officer or board of contract appeals has a second opportunity for administrative review. Unlike the departmental review, however, this GAO review is optional and is not a prerequisite to filing a court action..$^{51}$

The GAO has retained its authority to review the disbursement of money by the contracting officer in spite of the finality clause, but, like the courts, had prior to Wunderlich found itself limited to finding fraud or gross error implying fraud. ${ }^{52}$ While recognizing the hardship the finality clause may work on the private contractor in those cases where the contracting officer has erred in favor of the Government, the GAO, as the Government accounting agency, has been more concerned with its complete lack of success in making its reversal of a decision favorable to the contractor stick in court. Proof of fraud or gross mistake against the Government on the part of the Government's own agent under a contract dictated by the Government is a difficult burden to sustain. ${ }^{53}$ The GAO has taken the position that the Wunderlich decision, by requiring proof of actual fraud, makes it virtually impossible for the Office to fulfill its statutory duty of auditing and settling Government accounts. ${ }^{54}$ By S. 24, the McCarran Bill, which would give the GAO broad power to upset final administrative determinations and which is substantially the bill proposed

${ }^{50}{ }_{42}$ StaT. 24 (I92I), 3I U.S.C. \& 7I (I946). See Cable, The General Accounting Ofice and Finality of Decisions of Government Contracting Oficers, 27 N.Y.U.L. REv. 780, 783-85 (I952); see also note Ioo infra.

51 The Supreme Court has insisted that before filing suit an aggrieved contractor exhaust his administrative remedy before the department head or the appropriate board of appeals where the contract so provides. United States v. Holpuch Co., 328 U.S. 234, 239 (I946); United States v. Blair, 32I U.S. 730, 735 (I944); United States v. Callahan-Walker Construction Co., 3I7 U.S. 56, 6r (I942).

${ }^{52}$ See, e.g., Albina Marine Iron Works v. United States, $79 \mathrm{Ct}$. Cl. 7I4, 720 (I934); see also James Graham Mfg. Co. v. United States, 9x F. Supp. 7I5 (N.D. Cal. 1950) (motion for summary judgment against the Government granted).

${ }^{33}$ See United States v. Mason \& Hanger Co., 26o U.S. 323 (x922), holding that the Comptroller General was without power to deduct from monies due the contractor the amount of premium on a bond under a cost-plus contract where the contracting officer had approved reimbursement as a legitimate cost. For a collection of the cases since I922, see Braucher, Arbitration Under Government Contracts, I7 LAW \& CoNTEMr. Prob. 473, 489 n.I 6 (I952).

${ }^{54}$ Letter from Lindsay C. Warren, Comptroller General, Hearings, stipra note 32, at 5. The Wunderlich fraud test was applied against the Comptroller General in Leeds \& Northrup Co. v. United States, ror F. Supp. 999 (E.D. Pa. I95x). 
by Comptroller General Lindsay Warren, it frankly seeks a reversal of this situation. ${ }^{55}$

From the point of view of the contractor the administrative review procedure of the GAO is not too dissimilar from departmental review. If anything, it is more informal. The statutes under which the GAO is authorized to settle and adjust claims by and against the United States prescribe no definite form of procedure for the presentation and settlement of claims, leaving it entirely to the Comptroller General. Moreover, as an arm of Congress the GAO would appear to be excluded from the requirements of the Administrative Procedure Act, under Section 2 (a). ${ }^{56}$ On the other hand, there may be some advantage to arguing a case to accountants, rather than lawyers, where the issue is cost accounting; there may also be psychological satisfaction in dealing with an office closer to the source of payment. And, of course, if the amount is worth fighting about, it is nice to have a second chance before resort to the courts.

\section{The Wunderitch Decision and Repercussions}

Wunderlich involved a dispute between a large contractor and a contracting officer of the Bureau of Reclamation in the Department of the Interior over the proper charges for the use of the contractor's excavation equipment in the construction of the twomillion-dollar Vellecito Dam in southern Colorado. ${ }^{57}$ The difference in the computations was the sizable sum of $\$ 100,000$. Under Article I5, the fact disputes clause in the Government's standard construction contract, the officer's decision was final, subject only to a written appeal within 30 days to the "head of the Department or his duly authorized representative." Unlike the Defense Department's ASBCA review, in the Interior Department this means review by the Secretary himself, who, in

${ }^{55}$ S. 24 was passed by the Senate June 8, 1953. See 99 Cong. Rec. 4729-30, (May 6, I953) ; $i d$. at 6402, 6406 (June 3, I953). See SEN. REP. No. 32, 83d Cong., Ist Sess. (I953). H.R. 1839 , the companion bill, was not reported out of committee. The original bill, identical with S. 24, was S. 2487 , passed by the Senate July 3, I952, 98 Cong. Rec. 9059 (I952). See also 98 Cong. REc. 365, 6493 (1952). See SEv. REp. No. I67o, 82d Cong., 2d Sess. (1952); Hearings, supra note 32.

${ }^{5 e}$ Section 2 (a) provides: "Agency means each authority (whether or not within or subject to review by another agency) of the Government of the United States other than Congress ...." 60 STAT. 237 (I946), as amended, 5 U.S.C. § I00I (Supp. I952).

${ }^{57}$ The facts are fully set out in II7 Ct. Cl. 92 (I950). 
the Wunderlich case, fully approved the officer's decision without a hearing. ${ }^{58}$

The Supreme Court's decision to limit judicial review to the issue of fraud created considerable stir in business and legal circles. Editorials and news comments dinned on congressional ears without regard to party or section. ${ }^{59}$ Four remedial bills were introduced in the House, two in the Senate. ${ }^{60}$ Hearings were held on the McCarran Bill before a subcommittee of the Senate Committee on the Judiciary in February and March I952. ${ }^{61}$ The testimony had an odd twist. As expected, representatives of the private contractors and the construction trade associations ${ }^{62}$ assailed the decision in the strongest terms, borrowing some of $\mathrm{Mr}$. Justice Douglas' trenchant dissenting language. But the Government departments involved, with the exception of the Department of Justice, which had won the case, did not enter the expected defense of the status quo. In fact, the Department of Defense admitted the reasonableness of the contractors' argument and promised to return the disputes clause to its pre-Wunderlich meaning by administrative amendment. In this the General Services Administration, second only to Defense in volume of Government contracting, concurred. ${ }^{63}$ While failing to enact any

58 See note 43 supra.

${ }^{59}$ See, e.g., Engineering News Record, Dec. 6, I95I, p. 25. Senator McCarran inserted a law review article highly critical of the Wunderlich decision in the Congressional Record. 98 CoNG. Rec. 9307 (I952).

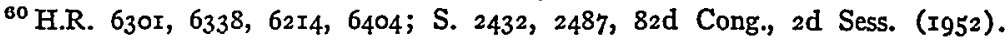
S. 2487 is the first McCarran Bill.

${ }^{61}$ Hearings, supra note 32.

${ }^{62}$ E.g., Associated General Contractors, National Association of River and Harbor Contractors. Several general associations also filed anti-Wunderlich letters with the committee. E.g., United States Chamber of Commerce, American Institute of Architects.

${ }^{63}$ The Defense Department revision, made effective by ASPR Revision No. 4, Sept. I5, I952, ASPR § 7-I03.I2, 2 CCH Gov'T CoNtracts Rep. If 29,363 (I953), applies to both supply and construction contracts. The General Services Administration revision applies only to construction contracts. GSA Reg. No. I3, effective June I9, I953, 2 CCH Gov't Contracts Rep. If 24,965 (I953). For the GSA current, old-style disputes clause used in supply contracts, see art. 22 of General Provision of FS Schedule, I CCH Gov'r CoNTRACTS REP. $\|$ I8,8I6 (GSA Form 28IC, March I95I). The present disputes clause for Defense Department contracts reads as follows:

Except as otherwise provided in this contract, any dispute concerning a question of fact arising under this contract which is not disposed of by agreement shall be decided by the Contracting Officer, who shall reduce his decision to writing and mail or otherwise furnish a copy thereof to the Contractor. Within 30 days from the date of receipt of such copy, the Contractor may appeal by mailing or otherwise furnishing to the Contracting Officer a written appeal addressed to the Secretary, and 
of the proposed remedial bills, Congress took direct action and broadened judicial review of Defense Department disputes clauses, tacking on a rider to the Defense Department Appropriation Act. ${ }^{64}$ Finally Wunderlich has spurred many private groups, including the American Bar Association, to become interested in this important business and legal aspect of our vast procurement program. ${ }^{65}$

\section{A. Enlarging the Scope of Review}

The proposed legislative and administrative changes were concerned primarily with increasing the scope of review of the contracting officer's decision or at least with stabilizing it on a preWunderlich basis. Actually, the only concrete legislative result of Wunderlich to date has been the rider tacked on to the Department of Defense Appropriation Acts of 1953 and 1954, which reads:

$\S 635$. No funds contained in this Act shall be used for the purpose of entering into contracts containing Article I 5 of the Standard Government Contract until and unless said article is revised and amended to provide an appeal by the contractor to the Court of Claims within ninety days of the date of decision by the Department concerned, authority for which appeal is hereby granted..$^{66}$

The Defense Department made no attempt to interpret the congressional mind but simply added to the disputes clause in its

the decision of the Secretary or his duly authorized representative for the hearing of such appeals shall unless determined by a court of competent jurisdiction to have been fraudulent, arbitrary, capricious, or so grossly erroneous as necessarily to imply bad faith, be final and conclusive. In connection with any appeal proceeding under this clause, the Contractor shall be afforded an opportunity to be heard and to offer evidence in support of its appeal. Pending final decision of a dispute hereunder, the Contractor shall proceed diligently with the performance of the contract and in accordance with the Contracting Officer's decision.

The clause may be modified to provide for intermediate appeal to the head of the procuring activity concerned. Contracts involving funds appropriated in the Department of Defense Appropriations Act, I953, 66 STAT. 537 (I952), also contain the following sentence at the end of the disputes clause: "Notwithstanding the provisions of this clause, the Contractor shall have such right of appeal to the Court of Claims as is provided by Section 635, Public Law 488, 82d Cong."

${ }^{64} 66$ STAт. 537 (r952) ; reenacted as Pub. L. No. I79, 83d Cong., Ist Sess. $§ 635$ (Aug. I, T953).

65 "The volume of [Government] contracts is staggering. For the fiscal year x953 an aggregate of $\$ 38$ billion for procurement requirements have been requested of Congress. During fiscal $195 \mathrm{I}$, the Ordnance Corps of the Army alone executed some 57,000 separate contracts for amounts in excess of $\$ 5,000$ apiece." Cook, Foreword to Symposium on Procurement Procedures of the Federal Government, I2 FED. B.J. 23 I (I952).

${ }^{B 6}$ See note 64 supra. 
construction contracts which will be paid from funds appropriated in the I953 Act that "the contractor shall have such right of appeal to the Court of Claims as is provided by Section 635 . . ." The rider was applied to construction contracts, and not to supply contracts, on advice of the GAO and presumably on the theory that article $I_{5}$ is the number of the standard disputes clause only in construction contracts. ${ }^{68}$

In its original form this rider would have flatly prohibited the use of the standard disputes clause in defense contracts. ${ }^{69}$ As watered down and enacted, it leaves many questions unanswered. Inasmuch as a contractor could always appeal to the Court of Claims, albeit not always successfully, it may not add anything to the court's power of review. On the other hand, if it is to be given some meaning under the usual canons of construction, it may mean that the Court of Claims is no longer bound by Wunderlich and pre-Wunderlich formulae in defense contract disputes and can in effect treat the question de novo. This is supported by reasoning that the only cause for liniting review of the contracting officer's decision to fraud issues is that the parties expressly agree that his decision will be final. Thus where the contract itself provides for administrative appeal, the administrative review is de novo. Similarly where the contract, even though under statutory compulsion, provides for appeal to the courts, there does not seem to be any reason for limiting that review to fraud. To permit de novo review by the courts would, however, remove much of the efficacy of the disputes clause. It may be that Congress intended this result on the theory that the expense of litigation and the limited chance of success would mean that in most cases the contracting officer's decision would stand.

The GAO ruling that the Section 635 requirement is limited to

\footnotetext{
${ }^{67}$ ASPR Revision No. 4, Sept. 15, 1952, supra note 63.

${ }^{68}$ Comptroller General's Decision No. B-Ir2635 (I952), 2 CCH Gov'r CoNTRACTS REP. I 61,405 (1952).

${ }^{69}$ H.R. Rep. No. I685, 82d Cong., 2d Sess. (I952), accompanying the I953 Defense Department Appropriation Bill which passed the House, incorporated the original § 635, which read in part: "No funds contained in this Act shall be used for the purpose of entering into contracts containing Article I5 $_{5}$ of the Standard Government Contract which reads as follows: ..." SEN. REP. No. I86r, 82d Cong., 2d Sess. I7-r8 (I952), suggested the amendment of H.R. 739r by deleting all of $\S 635$ (miscited as $\S 636$ ). H.R. CoNr. REP. No. $2483,82 d$ Cong., 2d Sess. (I952), reported the conferees in disagreement. The House receded from its position and concurred with the revised $\S 635$ given in the text. 98 Covg. Rec. 9433 (I952). The Senate agreed without discussion. 98 CoNG. REc. 95 II (I952).
} 
construction contracts would greatly reduce the area in which its interpretation is important. The question remains, however, whether the GAO has correctly interpreted the congresssional enactment. Was the reference to article I 5 a deliberate effort to limit the effect of the amendment or was it merely a slip of the pen? Neither committee nor congressional debates suggest what the true intention of Congress was. ${ }^{70}$ The urgency of these questions is perhaps lessened by the fact that the Defense Department voluntarily amended its standard disputes clause to read "final and conclusive ... unless determined by a court of competent jurisdiction to have been fraudulent, arbitrary, capricious, or so grossly erroneous as necessarily to imply bad faith." The General Services Administration has taken a similar step although it has limited its change to construction contracts. ${ }^{71}$

This administrative action, confined to two departments, has not halted the legislative process. Wunderlich, with Moorman in a supporting role, is directly responsible for S. 24, the McCarran Bill, which has passed the Senate in each of the last two sessions of Congress and awaits consideration by the House when Congress reconvenes in January. The Bill reads:

$\S \mathrm{I}$. That no provision of any contract entered into by the United States, relating to the finality or conclusiveness, in a dispute involving a question arising under such contract, or any decision of an adminstrative official, representative, or board, shall be pleaded as limiting judicial review of any such decision to cases in which fraud by such official representative, or board is alleged, and any such provision shall be void with respect to any such decision which the General Accounting Office or a court, having jurisdiction, finds fraudulent, grossly erroneous, so mistaken as necessarily to imply bad faith, or not supported by reliable, probative, and substantial evidence.

$\S 2$. No Government contract shall contain a provision making final on a question of law the decision of an administrative official, representative, or board. ${ }^{72}$

This Bill, as reported out, was broadened in favor of the antiWunderlick and anti-Moorman interests and goes far beyond the

${ }^{70}$ See note 69 supra. Other questions suggested by the language of the rider are its effect on the six-year statute of limitations on contract claims and the availability of review in the district courts where the claim is for less than \$Io,000.

${ }^{71}$ See note 63 supra.

${ }^{72}$ S. 24,83 d Cong., Ist Sess. (I953), as read on the floor of the Senate after amendment, Feb. 4, I953. See note 55 supra. 
Defense Department's voluntary change designed to return judicial review to its pre-Wunderlich form. In addition to incorporating the simple "gross error" test which the Supreme Court has repeatedly rejected since the Kihlberg case, the McCarran Bill would upset any administrative decision "which the General Accounting Office or a court, having jurisdiction, finds ... not supported by reliable, probative, and substantial evidence." The last phrase was an amendment to the original McCarran Bill and was sponsored by several witnesses at the Senate hearing. ${ }^{73}$ One of the six bills introduced in the $82 \mathrm{~d}$ Congress incorporated a similar test. ${ }^{74}$ Unlike the Associated General Contractors, which had proposed a complete review de novo in the Court of Claims, ${ }^{75}$ the sponsors of the altered wording appear to have had in mind the well-known "substantial evidence" rule. ${ }^{76}$

Review of an agency decision under the "substantial evidence" rule has been compared in scope with the review of a jury verdict. This traditionally is narrower than review of a trial judge's findings, which must be "clearly erroneous" to be reversed. ${ }^{77}$ Ordinarily agency review presupposes a record made after a full-dress hearing, which can be scrutinized by the appellate court to determine whether there is substantial evidence on the whole record to support the agency's determination. ${ }^{78}$ In Government contract disputes, the informality of the contracting officer's decisionmaking and of the contract board's appeal procedure, in particular outside the Defense Department, leaves considerable doubt whether there exists a record amenable to "substantial

${ }^{73}$ Hearings, supra note 32 , at 53-54 (McGuire), 54-59 (Kline).

${ }^{74}$ H.R. $6338,82 \mathrm{~d}$ Cong., $2 \mathrm{~d}$. Sess. (I952).

${ }^{75}$ Testimony of Gaskins, Hearings, supra note 32, at 33. Gaskins, agreeing with the AGC position, cited as precedent the Tax Court's jurisdiction over renegotiation cases. See Braucher, The Renegotiation Act of 1951,66 HARv. L. REv. 270, 305-07 (1952).

${ }^{76}$ See Davis, Adminustrative Law $\S 254$ (195I). Actually, the phraseology is identical with $\S 7$ (c) of the APA: "no sanction shall be imposed or rule or order be issued except upon consideration of the whole record or such portions thereof as may be cited by any party and as supported by and in accordance with the reliable, probative, and substantial evidence" (italics supplied), rather than the language of the judicial review section, $\S$ Io(e) (5), "unsupported by substantial evidence," to which it is probably intended to refer.

${ }^{77}$ See Davis, Admunistrative LAw $\S 254$ (195 I) ; Stern, Review of Findings of Administrators, Judges and Juries: A Comparative Analysis, 58 HARv. L. Rev. 70 (1944).

${ }^{78}$ See Universal Camera Corp. v. NLRB, 340 U.S. 474 (I95I); Jaffe, Judicial Review: "Substantial Evidence on the Whole Record," 64 HARv. L. REv. I233 (I95I). 
evidence" review. This is particularly true where the record does not include evidence adduced at a hearing where both parties are represented. In such a case the courts might feel obligated to go beyond the incomplete record and in effect review de novo in order to determine whether there is substantial evidence, given all the relevant facts, to support the conclusion of the contracting officer. If they did not do so, "substantial evidence" would take on a new and dubious meaning, simply that the evidence relied on by the contracting officer could reasonably lead to his conclusion, as opposed to the usual qualitative-quantitative determination of whether the evidence relied on, when weighed against all the other evidence introduced by both parties, is reasonably adequate to support the decision. ${ }^{79}$

But the lack of a record is not the only difficulty. The forum to which the contract appeal is taken is not an appellate court. The Court of Claims (and the district courts in so far as they act concurrently) is much like any other trial court though using the commissioner system in lieu of the jury. This means that, while it may grant money judgments against the United States along with limited equitable relief, aside from its appellate powers under the Indian Claims Commission Act ${ }^{80}$ and the Federal Tort Claims Act, ${ }^{81}$ it has no jurisdiction to correct errors in a record by process of remand. ${ }^{82}$ It is true that it may consider the record of the contracting officer and of the board of contract appeals but only as a part of the total record, on which the commissioner and the court, in turn, make independent findings of fact and con-

${ }^{78}$ See Consolidated Edison Co. v. NLRB, 305 U.S. I97, 229-3I (I938) ; Stason, "Substantial Evidence" in Administrative Law, 89 U. of PA. L. Rev. 1026, I036-39 (I94I); Davis, AdMInISTrative LaW § 254 (I95I).

so 60 STAT. I054, 25 U.S.C. \& 70(s) (1946).

81 60 Srat. 842 (I946), as amended (codified in scattered sections of Title 28 of the United States Code). Review by the Court of Claims instead of a court of appeals is obtainable upon written consent of all appellees to the district court

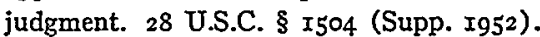

${ }^{82}$ See United States v. Jones, 336 U.S. 64r, 670 (r949), where the Court advanced as the major reason for a restrictive view of the jurisdiction of the Court of Claims the inability of that court to render any judgment other than one for the payment of money. Thus, in considering an order of the ICC, the Court of Claims, if it found the order invalid, had no alternative but to proceed to a final decision of its own. Nor should Pub. L. No. I58, 83d Cong., Ist Sess. (July 28, I953), making the Court of Claims a constitutional, rather than a legislative court, and negating Williams v. United States, 289 U.S. 553 (1933), affect the specific powers of the Court of Claims. See Hart and Wechsler, The Federai Courts and the FederaI SYSTEM 348-5I (r953). 
clusions of law. It is in no way comparable to a circuit court reviewing an agency decision "on the whole record." While Congress could give the Court of Claims appellate jurisdiction over contract disputes, the grant of such powers should be made explicit and not left as an implication from the use of the phrase "substantial evidence."

The Department of Justice has opposed the application of anything broader than the fraud test to Government contract disputes, anticipating that it "would constitute an open invitation to a flood of litigation" ${ }^{83}$ on disputed issues of fact now foreclosed by the disputes clause. Proponents of this view suggest that the relaxation of the fraud rule would serve only to "clog the calendar of the Court of Claims" and give the contractor an additional review which he has not bargained for. ${ }^{84}$ Nevertheless, the knife may cut both ways. If the courts' applying the McCarran Bill's "substantial evidence" test limits review to the sufficiency of the evidence relied on by the administrative tribunal, the contractor going to the Court of Claims bound by the record of a board of contract appeals may be at a serious disadvantage. In the end he may be worse off than he would be if the board's decision were reviewed under the Defense Department's liberalized fact disputes clause for being "fraudulent, arbitrary, capricious, or so grossly erroneous as necessarily to imply bad faith."

At its September I952 meeting the American Bar Association's House of Delegates took a somewhat different approach to the problem, unanimously adopting a resolution submitted by its Section on Administrative Law: "Be it resolved that it is the opinion of the American Bar Association that the determination of federal contracting officers and reviewing officials under the finality clause of government contracts should be subject to judicial review, in accordance with the criteria of the Administrative Procedure Act, and that the Section on Administrative Law be authorized and directed to advance appropriate legislation to that end." 85

In August 1953, the ABA's Section on Administrative Law authorized its Committee on the Finality Clause to sponsor as a substitute for S. 24 at the second session of the 83 d Congress, meeting next January, the following proposal: "Notwithstanding

${ }^{83}$ Testimony of Phillips, Hearings, supra note 32 , at 16 .

${ }^{84} \mathrm{Id}$. at $\mathrm{I6}$-18.

8577 A.B.A. REP. I30 (I952). 
the presence in any contract entered into by the United States of a provision relating to the finality or conclusiveness of any decision of an agency official, board or other representative on questions of law or fact arising under such contract, judicial review as provided in Section to of the Administrative Procedure Act may be had of any such decision by the contractor." 86

On first impression it would appear that the ABA resolution, as implemented by the above bill, avoids all the difficulties of the McCarran Bill save one, namely, the "substantial evidence" test, as incorporated in APA Section IO(e)(5). On closer scrutiny, it becomes apparent that it poses certain questions arising out of the intricacies of Section Io itself.

As might be expected, the protracted legislative history of the APA throws no light on whether the legislators in r946 intended to bring adjudication of Government contract disputes within the Act. $^{87}$ To determine the applicability of Section Io thus requires direct study beginning with the exceptive clause: "Except so far as (I) statutes preclude judicial review or (2) agency

${ }^{86}$ Letter from David Reich, vice-chairman of the Committee, August 3I, I953. The House Committee on the Judiciary is scheduled to take up H.R. I839, the companion bill to S. 24 , in the second session of the $83 \mathrm{~d}$ Congress. A one-day hearing was held during the last days of the first session. A bill similar in purpose but different in approach to the ABA proposal was one of the six introduced in the second session of the 82d Congress. H.R. 6406 provided for the amendment of $\S$ Io of the APA to read:

Except so far as (x) statutes preclude judicial review or (2) agency action is by law committed to agency discretion -

(a) Right of review. -

(I) Any person suffering legal wrong because of any agency action, or adversely affected or aggrieved by such action within the meaning of any relevant - statute, shall be entitled to judicial review thereof.

(2) Notwithstanding the provisions of section 2(a) (4) hereof and the two exceptions in the first paragraph of section ro hereof, any person who shall hereafter suffer or be threatened with any actual injury or loss as the result of agency action in excess of statutory jurisdiction, authority, or limitations, or short of statutory right, or as the result of arbitrary and capricious agency action amounting to an abuse of discretion, whether or not such injury or loss has heretofore conferred upon such person standing to sue, shall be entitled to judicial review thereof.

Recently, Congress has made wage determinations under the Walsh-Healey Act (originally exempt from rule-making under APA $\S 4$ as a matter relating to public contracts) subject to review under $\S$ ro of the APA. Defense Production Act Amendments of I952, 66 STAT. 308, 4I U.S.C.A. § 43(a) (Supp. r953). Several bills were introduced at the first session of the $83 \mathrm{~d}$ Congress designed to repeal this amendment.

${ }^{87}$ See Sen. Doc. No. 248, 79th Cong., 2d Sess. (I946). Public contracts and other proprietary matter were exempted from APA $\$ 4$ on rule-making "because in those cases the Government is in the position of an individual citizen concerned with its own property, funds and contracts." Id. at 358 . 
action is by law committed to agency discretion - (a) Any person suffering legal wrong because of any agency action, or adversely affected or aggrieved by such action within the meaning of any relevant statute, shall be entitled to judicial review thereof." ${ }^{88}$ Clearly, no statute presently precludes review of administrative determinations of contract disputes. The real question is whether contract dispute settlement is "agency action . . . by law committed to agency discretion." In as much as the Defense Department's fact disputes clause is a regulation implementing the Armed Services Procurement Act of $1947{ }^{89}$ it is arguable that Congress by law has delegated final action on contract disputes to the procurement agency's discretion. On the other hand, even if this were true, the Defense Department's recent amendment to its disputes clause clearly envisages court review of the agency's discretion on specific grounds. ${ }^{90}$ Certainly, if Congress should pass the ABA proposal, it does not seem likely that Section ro of the APA under which the proposal makes review available would be interpreted so as not to apply at all to the very situation which Congress intended to bring under its coverage.

Assuming that judicial review of Government contract disputes is not excluded under Section Io, the next question is whether the remaining subsections, (b) through (e), are applicable. No difficulty arises until one examines the criteria in Section Io(e) on scope of review. Clearly, under our previous analysis, the "substantial evidence" rule is a misfit as applied to the decisions of boards of contract appeals. ${ }^{91}$ But it is evident that by its own definition, Section ro(e) (5) is not intended to apply, for it reads: "the reviewing court shall . . . (B) hold unlawful and set aside agency action, findings, and conclusions found to be . . . (5) unsupported by substantial evidence in any case subject to the requirements of sections 7 and 8 or otherwise reviewed on the record of an agency hearing provided by statute ...." In as much as the ABA Bill is restricted to Section Io, and does not

8860 STAT. 243, 5 U.S.C. \$ 1009 (1946).

8962 STAT. 2I (I948), 4I U.S.C. \$§ I5I et seq. (Supp. I952). The same can be said for the GSA disputes clause under the Federal Property and Administrative Services Act of I949, 63 STAT. 393 (I949), 4I U.S.C. § 25I (Supp. I952).

80 "unless determined by a court of competent jurisdiction to have been fraudulent, arbitrary, capricious, or so grossly erroneous as necessarily to imply bad faith. ..." See note 63 supra.

${ }^{81}$ See pp. 237-39 supra. 
refer to Sections 7 and 8, which apply only to hearings required by statute, and since no statute requires a board of contracts appeal hearing, it would appear that the "substantial evidence" rule should not be invoked by a court reviewing a "decision of an agency official, board or other representative on questions of law or fact arising under such contract."

Under Section ro(e), agency action can also be set aside if it is "(I) arbitrary, capricious, an abuse of discretion, or otherwise not in accordance with law," and it is presumably this phrase on which contractors would rely most. ${ }^{22}$ If this is so, it may be wondered whether Section Io would add anything to the administrative amendment the Defense Department and General Services Administration have made to their disputes clauses, which includes similar language. ${ }^{93}$ To be sure, it would have an impact on other procurement agencies, such as the Interior Department, which have not as yet amended their disputes clauses, and it would serve as a guarantee to contractors against subsequent administrative reversal of policy. ${ }^{94}$

\section{B. New Authority in the GAO: Auditor or Court?}

Proposed changes in the disputes clause set-up have not been limited to expansion of the scope of court review. During the Senate hearings on the finality clause legislation, the Comptroller

92 "( 2 ) contrary to constitutional right, power, privilege, or immunity; (3) in excess of statutory jurisdiction authority, or limitations, or short of statutory right; (4) without observance of procedure required by law ...." are presumably not relevant standards because administrative decisions under the disputes clause are not governed by constitutional, statutory, or common law provisions. "(6) unwarranted by the facts to the extent that the facts are subject to trial de novo by the reviewing court ...." is inapplicable because the facts' presented to the administrative board are by contract not subject to de novo trial. In fact, under the Kihlberg rule the court could examine the facts only for the purpose of discovering "fraud or such gross mistake as would necessarily imply bad faith, or failure to exercise an honest judgment." Wunderlich's excision of all this formula but fraud underscores the non-de-novo nature of the court review. An example of a situation where judicial review consists of a trial de novo is reparation orders under the Interstate Commerce Act and the Packers and Stockyards Act which by statute are given only prima facie weight. See Atr'y Gen. Manual on the APA rog-Io (I947).

93 "fraudulent, arbitrary, capricious, or so grossly erroneous as necessarily to imply bad faith ...." See note 63 supra.

94 Finally, it should be noted that the ABA bill apparently provides for direct review of a contracting officer's decision without exhaustion of the administrative remedy before the appropriate board of contract appeals. See p. 240 supra. This would seem to have been an unintentional oversight in drafting. 
General persuaded the subcommittee to modify the original McCarran Bill to give the GAO broader power to upset final administrative determinations beyond Wunderlich's narrow "fraud and fraud alone" exception, and to prohibit the all disputes type of clause which had been approved by Moorman. ${ }^{95}$ The pending bill is thus, in effect, a GAO bill. If enacted, it would invest the GAO with the power - which it has never had - to upset an administrative decision which it finds "grossly erroneous" or "not supported by reliable, probative, and substantial evidence."

It is not clear whether the Bill would make a GAO reversal of the contracting officer bind the courts or whether it merely permits a broader scope of review subject, as in the past, to a judicial determination of whether the GAO decision was correct. ${ }^{96}$ The Bill says the finality provision is void if the GAO or a court having jurisdiction finds the contracting officer's decision is not supported by substantial evidence. Read literally it would indicate that the GAO was an alternative review tribunal open to both the contractor and the Government and with the power of final decision. If this reading is correct, by placing the GAO on a par with the courts and allowing it to overturn a contracting officer's decision not supported by substantial evidence the McCarran Bill would put the contractor in a very uncertain financial position. Although it would provide the contractor with an alternative review of decisions favorable to the Government, the GAO is more concerned with scrutinizing decisions favorable to the contractor. In its capacity as overseer of Government disbursements the GAO is inevitably cost conscious in its view of contract disputes. Such an outlook, while necessary in an auditor, is hardly the sole guide to successful operation of a business or to impartial adjudication of disputes where other factors - such as the maintenance of a favorable business attitude, the necessity

\footnotetext{
${ }^{95}$ Yates, Assistant Comptroller General, testifying, Hearings, supra note 32 , at 4-I3.

${ }^{96}$ But note the statement in the Senate subcommittee's report on S. 24, SEN. REP. No 32, 83d Cong., Ist Sess. (I953):

The committee wishes to point out with respect to the language contained in the bill, "in the General Accounting Office or a court, having jurisdiction," that it is not intended to narrow or restrict or change in any way the present jurisdiction of the General Accounting Office, either in the course of a settlement or upon audit; that the language in question is not intended either to change the jurisdiction of the General Accounting Office or to grant any new jurisdiction, but simply to recognize the jurisdiction which the General Accounting Office already has.

It is impossible to reconcile the Bill's language with this disclaimer. In any contest the language of the Bill would presumably prevail.
} 
of getting a job done, and protection of the private contractor may be equally important considerations. ${ }^{97}$ On its own motion after investigation or at the instigation of some executive department the GAO could deny payment or demand payment back after a considerable lapse of time without the possibility of court review. The statute does not disclose how the GAO would enforce its demand for payment back. Presumably there would have to be court action to force compliance with the administrative order. ${ }^{98}$ The net result could be little finality to the Government's word on the countless matters embraced under the disputes clause. Contractors might be placed in the position of being unable to close their books until the three-year statute of limitations on the GAO's investigative activities had run. ${ }^{99}$ Surety companies writing performance and payment bonds and banks financing longterm contracts might have to look to their security. ${ }^{100}$

It may be that the McCarran Bill is not intended to disturb the subordinate position of the GAO but merely broadens its

97 The declaration of policy of the Contract Settlement Act of I944, 58 STAT. 649 (I944), 4I U.S.C. $\S$ IOI (I946), noted the subordinate importance of the auditing function in Government business, declaring one objective of the statute to be "to use all practicable methods compatible with the foregoing objectives [which included maximum production during war, expeditious reconversion, assurance to contractors of speedy and equitable final settlement of claims, and adequate interim financing until such settlement] to prevent improper payments and to detect and prosecute fraud" (emphasis supplied).

${ }^{88}$ See, e.g., the Civil Aeronautics Act, 52 STAT. 2025 (I938), 49 U.S.C. § 647 (a), (b) (I946), which permits a party in interest or the CAB to apply to the district court for the enforcement of $\mathrm{CAB}$ rules and orders. Enforcement of administrative orders invariably raises the question of how conclusive the administrative order is and whether the court review should be merely perfunctory. For a general discussion, see Davis, Admenistrative LAW \$220 (I95I).

${ }^{99}$ Armed Services Procurement Act of 1947 , as amended, 65 STAr. 700 (I95I), 4x U.S.C. $\$ 153$ (c) (Supp. I952):

All contracts negotiated without advertising pursuant to authority contained in this chapter shall include a clause to the effect that the Comptroller General of the United States or any of his duly authorized representatives shall until the expiration of three years after final payment have access to and the right to examine any directly pertinent books, documents, papers, and records of the contractor or any of his subcontractors engaged in the performance of and involving transactions related to such contracts or subcontracts.

See 2 CCH Gov'r CoNTRACTS REP. If 24,858, § 209.03 (a) (I952). The same provision appears in the Federal Property and Administrative Services Act of I949, as amended, 63 StaT. 395 (I949), 4I U.S.C. \& 254(c) (Supp. I952).

${ }^{100}$ See letter from O. P. Easterwood, Jr., Hearings, supra note 32, at II9-2I:

It is suggested that the surety companies who write the performance and payment bonds and the banks who finance the contractor would be very loath to bond or lend money to contractors where the possibility or probability existed that the Comptroller might differ with an administrative decision of a contracting officer made in favor of a contractor and could later collect back the difference between their substituted judgment and that of a contracting officer from a contractor. 
scope of review. If so, the contractor could still find a favorable contracting officer's decision reversed in court on substantial evidence grounds since the GAO may request the Attorney General to enforce its decision in the district court. ${ }^{101}$

In any event, as the Bill now stands, the effect of the GAO decision on subsequent judicial action needs clarification if its effect on the contractor is to be understood. Moreover, regardless of the intended position of the GAO in the judicial hierarchy, it may be undesirable to cause a weakening of the contractor's position by permitting a continuing review of the facts by the Government under the "substantial evidence" rule. The contractor's need for financial certainty seems much greater than that of the Government.

\section{Fate of the All Disputes Clause}

Section 2 of the McCarran Bill, prohibiting any provision in a Government contract "making final on a question of law the decision of an administrative official, representative, or board," presents another problem. Sponsored mainly by the GAO, this section is aimed at the I950 Moorman case where the Supreme Court finally convinced the Court of Claims that the all disputes clause was valid. It is difficult to forecast the exact impact of this proposed prohibition. While the Navy Department uses an all disputes clause in all of its cost-plus-fixed-fee contracts, the Department of the Army since World War II has been relying principally on the fact disputes clause in both its supply and construction contracts. ${ }^{102}$ Nowhere in the hearings on the proposed legislation is there any indication that the procurement

10128 U.S.C. $\$ 1345$ (Supp. I952). The recovery of debts due the United States was originally entrusted to the GAO, 28 STAT. 206 (I894), as amended, 3 I U.S.C. $\$ 93$ ( 1946 ), but this function was transferred to the Department of Justice in I933. Exec. Order No. 6166 (June Io, I933), following 5 U.S.C. $\$$ I32 (I946).

The Government may obtain a judgment in the Court of Claims on the amount determined to be due from the contractor but only where the contractor has applied to the proper department of the Government for settlement of his account. Pub. L. No. 158,83 d Cong., Ist Sess. $\S 9$ (July 28, I953). Presumably this will not be the case where the contracting officer's decision favors the contractor.

102 Kennedy, The Conclusiveness of Administrative Findings in Disputes Arising Under Government Contracts, 4 Baylor L. Rev. I60, I6I-62 (I952). See Puget Sound Bridge \& Dredging Co. v. United States, ro7 F. Supp. 749 (Ct. Cl. I952) (all disputes clause in Navy shipbuilding contract). Prior to the Moorman case, the Department of the Army made wide use of the "Claims, Protests and Appeals" article (in effect an all disputes clause) in its construction contract specifications. Kennedy, supra, at I6I. 
agencies would strenuously object to the elimination of the all disputes clause.

For centuries the problem of whether a question is of law or fact has plagued common law judges. The Attorney General's Committee on Administrative Procedure took a dim view: "In numerous decisions courts have held that specific issues involved were questions of fact or questions of law. But definite criteria for ascertaining confidently which is which prior to court decision have not yet developed . . . . What one judge regards as a question of fact another thinks is a question of law." 103

Apart from Justice Black's dictum in Moorman, ${ }^{104}$ the one recent case where the Court has seriously considered the law-fact distinction is United States v. Callahan-Walker Construction Co. ${ }^{105}$ There the Court, applying the facts disputes clause to an equitable adjustment under the contract, unanimously reversed the Court of Claims, holding that an "equitable adjustment" of the contractor's additional payment for extra work involved merely the ascertainment of the cost of digging, moving, and placing earth, and the addition to that cost of "a reasonable and customary allowance for profit," and these were "inquiries of fact" for which article I 5 provided the only avenue for relief. Signs like Callahan-Walker point toward Supreme Court liberalization of the "facts" in the fact disputes clause - a tendency which the procurement agencies may feel obliged to encourage if Section 2 of the McCarran Bill is adopted.

\section{CONCLUSIONS AND RECOMMENDATIONS}

It is perhaps a little late to ask whether a Government contract is something other than a contract. There is some evidence that it is but a convenient administrative device for the Government to get its procurement work done and that administrative de-

${ }^{103}$ Rep. AtT'y Gen. Comar. Ad. Proc. 88, go (rg4I). See also Paul, Dobson v. Commissioner: The Strange Ways of Law and Fact, 57 HARv. L. REv. 753 (r944). The law-fact distinctions in Government contract cases are no exception. Compare Davis v. United States, 82 Ct. Cl. 334 (I936), with United States v. Lundstrom, I39 F.2d 792, 795 (9th Cir. I943), and Blair v. United States, r64 F.2d II5, Ix6 (5th Cir. I947). See Notes, 37 CoRNELx L.Q. 493, 499 (I952), I37 A.L.R. 530 (I942).

104 "The oft-repeated conclusion of the Court of Claims that questions of 'interpretation' are not questions of fact is ample reason why the parties to the contract should provide for final determination of such disputes by a method wholly separate from the fact-limited provisions of Art. I5." 338 U.S. 457,463 (I950).

${ }^{105} 3$ I7 U.S. 56 (I942). 
cisions of the Government's officers should be treated no differently from other administrative orders which affect private interests. Be that as it may, contract notions are so deeply imbedded in the thinking of judges and businessmen that it would be revolutionary for one to deny their expectation that an individual or corporation contracting with the Government will be fully protected with traditional rights and remedies. ${ }^{106}$ The basic question is whether the present state of the law under the Wunderlich rule fulfills these expectations, while permitting the Government to get its contracting done efficiently, inexpensively, and expeditiously.

Assuming that under the present dispensation commercial arbitration is unavailable ${ }^{107}$ and that the Government will not sacrifice its disputes machinery, our problem is to create an arbiter of contract disputes who will be both unbiased and competent. From the standpoint of competence, the contracting officer who is close to the day-to-day operation of a Government supply or construction contract seems indispensable; from the standpoint of lack of bias, a nisi prius court best fits our common law thinking. The problem, boiled down then, is, can we create a system which will embrace both considerations?

Clearly neither Mr. Justice Minton's "fraud and fraud alone"

${ }^{100}$ See Grismore, Contracts with the United States, 22 MrCH. L. REv. 749, 764 (I924): "It is not asking much to expect the Government to live up to those rules and principles to which it exacts adherence from the citizen. . . In a commercial age the Government must engage in business, and if it is to do this effectively it must of necessity obey those rules which businessmen have developed for their governance ...." See also Maguire and Zimet, Hobson's Choice and Similar Practices in Federal Taxation, 48 HARV. L. Rev. I28I, I299 (I935): "If we say with Mr. Justice Holmes, 'Men must turn square corners when they deal with the Government,' it is hard to see why the government should not be held to a like standard of rectangular rectitude when dealing with its citizens."

${ }^{107}$ See Braucher, Arbitration Under Government Contracts, I7 LAw \& CoNTEMP. PROB. 473, 485-86, 5or (I952) (concluding that the Government would not accept compulsory arbitration, and that experience under the Contract Settlement Act demonstrates that discretionary arbitration would not be widely used). The cases reveal sporadic use of arbitration. A recent example is George J. Grant Construction Co. v. United States, Iog F. Supp. 245 (Ct. Cl. I953), where, despite the absence of express statutory authority, an arbitration provision similar to the AIA standard procedure was approved. See Brief for the United States, p. I38. See also GrASKE, Law of Government Defense Contracts $\$ \S$ I57-63 (I94I); Maddren, $A d-$ ministrative and Judicial Machinery, Io LAW \& ConteMp. PROB. 659, 680 (I944) (discussing H.R. 3665 , designed to substitute arbitration for the disputes clause); Note, 50 YALE L.J. 458 (I94I). For a recent example of an ineffective arbitration clause, see Aktiebolaget Bofors v. United States, I94 F.2d I45 (D.C. Cir. I95I). 
test nor the lately deposed "implied bad faith" test (which together comprise the Kihlberg formula) is adequate. They are, as we have seen, a product of the horse and buggy contract age. In the late nineteenth century the Supreme Court used the Kihlberg formula interchangeably in Government and private contract cases. Its justification in private contract litigation was based on a desire not to substitute the jury for the expert who had presumably been freely chosen by both parties, though admittedly in the employ of one. It may well be that the early Government contracts with which the Supreme Court dealt were as freely bargained for as were the private contracts, and the Army engineer as independent as the private engineer, architect, or other expert. But with the phenomenal growth of Government contracting, the exclusive use of the standard form contract, and the changing role of the contracting officer from expert to Government agent, neither of these assumptions holds true. Hence, it is a real question whether the Kihlberg test, let alone Wunderlich, adequately protects the contractor from the arbitrary decision of a contracting officer even as reviewed by his department head or the designated appeals board.

What of the Defense Department's amendment to the disputes clause which purports to return it to its pre-Wunderlich meaning by conferring jurisdiction on the court limited by the test "fraudulent, arbitrary, capricious, or so grossly erroneous as necessarily to imply bad faith"? 108 Although the words "arbitrary" and "capricious" go beyond the strict Kihlberg formula, they would appear to be a fair concession to contractors, particularly in view of the increasingly familiar APA language. While the GSA has also liberalized its disputes clause for construction contracts, the adequacy of such adminstrative amendment as a general solution largely depends on whether other procurement agencies will follow suit.

While eliminating the words of art, "arbitrary" and "capricious," the McCarran Bill would add two new types of review to the pre-Wunderlich test, namely, "gross mistake" and "substantial evidence." It is now evident that the "substantial evidence" type of review would be singularly inappropriate if applied by the Court of Claims to an administrative board of contract ap-

${ }^{108}$ Query whether the Defense Department may "confer" jurisdiction on the courts to review in accordance with a strict administrative formula, or whether this is a partial ouster of jurisdiction. 
peals. While it widens the scope of judicial review, the "gross mistake" test which the Court of Claims had sporadically, and evidently improperly, used prior to Wunderlich, fits the disputes problem much better. In the hands of a careful court it would not result in the substitution of the court's judgment for the contracting officer's findings.

Certainly, most alarming of the innovations proposed by the McCarran Bill is that granting to the GAO the status of a Court of Claims. In addition to creating possible double expense to the Government, this innovation could undermine the security and bankable quality of Government contracts which Congress has sought to increase through the 1940 Assignment of Claims Act ${ }^{109}$ and in diverse ways.

While the prohibition against the all disputes clauses may seem somewhat academic at the moment with the Defense Department, the largest procurement agency, committed almost exclusively to the fact disputes clause, the worst that can be said is that it may accentuate the difficulty courts have in drawing the line between law and fact. ${ }^{110}$

The ABA proposal, if amended to take care of the difficulties pointed out in the discussion above, seems to be a far more satisfactory solution than the McCarran Bill. It has the additional merit that it would apply retroactively to contracts negotiated before the disputes clause amendment. In bringing Government contract disputes within the APA, the proposal also serves to point up the administrative nature of a Government contract. ${ }^{111}$

Another, and not necessarily alternative, solution would be to improve the administrative disputes machinery. Decisions of the contracting officer could be better articulated, without necessity for undue formality. The hearing before the boards of other

${ }^{100} 54$ STaT. 1029 (I940), as amended, 3I U.S.C. § 203 (Supp. 1952).

110 Obviously $\S 635$, the confusing rider to the Defense Department Appropriation Bills of I953 and I954, should be eliminated before it leads to troublesome litigation. See p. 234 supra.

111 Continental law has, in the recent words of a prominent scholar, approached the same problem by setting up a category of "administrative contracts" and "allocating the matter to administrative law and jurisdiction, under which the private party may obtain injunctions or damages and is, on the whole, not much worse off than under a private law contract .... The relative prevalence of public policy or private interests must decide whether a transaction involving a public authority is a private law contract, in which both parties are in a position of equality, or a public law transaction, where the public authority enjoys unilateral privileges." Friedmann, Law and Soctai, Change in Contemporart Britain 62, 64 (I95I). 
procurement agencies could approximate more closely the informal, yet full, hearing afforded by the ASBCA. Opinions could be published and made available. Steps could be taken to strengthen the independence and impartiality of the boards. ${ }^{112}$ The result would be an administrative appeal in which the private parties had confidence and against which charges of bias and unfairness would not stand. Under such circumstances it would not seem necessary to widen the Court of Claims' review beyond the "gross mistake" test or the ABA proposal. To enable contractors to take inexpensive appeals from adverse contracting officers' decisions, the boards of Defense and GSA could travel on circuit as does the Tax Court; and to make judicial review more available, the present Tucker Act limitation in the district courts could be raised from $\$ 10,000$ to at least $\$ 100,000 .^{113}$

${ }^{112}$ See letter from O. P. Easterwood, Jr., Hearings, supra note 32, at I20:

It would seem that the independence of the Board could be better established and the impartiality carried out in great detail if the Board reported only to the Secretary of Defense and had no particular allegiance to any of the Secretaries of the respective services. By the same token, an independent appeal board could be required, for example, under the General Services Administration to handle contracts administered by the Bureau of Reclamation, Civil Aeronautics Authority, etc.

113 The $\$ 10,000$ figure was established in 1887 , when the value of the dollar was markedly greater than what it is today and the volume of Government contracting considerably smaller. See note II supra. 